\title{
A Historiometric Examination of Machiavellianism and a New Taxonomy of Leadership
}

\author{
Katrina Bedell, Samuel Hunter, Amanda Angie, \& Andrew Vert \\ University of Oklahoma
}

Although researchers have extensively examined the relationship between charismatic leadership and Machiavellianism (Deluga, 2001; Gardner \& Avolio, 1995; House \& Howell, 1992), there has been a lack of investigation of Machiavellianism in relation to alternative forms of outstanding leadership. Thus, the purpose of this investigation was to examine the relationship between Machiavellianism and a new taxonomy of outstanding leadership comprised of charismatic, ideological, and pragmatic leaders. Using an historiometric approach, raters assessed Machiavellianism via the communications of 120 outstanding leaders in organizations across the domains of business, political, military, and religious institutions. Academic biographies were used to assess twelve general performance measures as well as twelve general controls and five communication specific controls. The results indicated that differing levels of Machiavellianism is evidenced across the differing leader types as well as differing leader orientation. Additionally, Machiavellianism appears negatively related to performance, though less so when type and orientation are taken into account.

\footnotetext{
Although outstanding leaders are characterized by the substantial impact they have on the organizations in which they work and the broader society in which we live (Gardner, 1993), there is relatively little known with regard to their psychological make-up (Deluga, 2001). Given the influence of one's psychological make-up on decision-making and problem-solving effectiveness (Renshon, 1998), it seems relevant to examine the psychological characteristics of outstanding leaders. One such characteristic is that of Machiavellianism, a social influence process emphasizing the use of
}

politics, power, and expressive behavior (Christie \& Geis, 1970a). A number of researchers have found Machiavellianism of interest due to its potential predictive power with regard to charismatic leadership (Deluga, 2001; Gardner \& Avolio, 1995, 1998; House \& Howell, 1992). Because charismatic and transformational leadership can account for many incidents of exceptional leadership, this relationship is of substantial importance (Howell \& Avolio, 1992; Lowe, Koreck, \& Sivasubramiam, 1996; Yorges, Weiss, \& Strickland 1999).

Until recently transformational and charismatic leadership have been the primary typologies of outstanding leadership. However, in light of a series of studies by Mumford and colleagues it appears that 1) there are alternative forms of leadership and 2) these leaders are cognitively, behaviorally, and developmentally different from each other (Mumford, in press). In fact, it appears that charismatic, ideological, and pragmatic leaders use characteristically different methods of influence. Charismatics, for example, use an emotionally evocative, future oriented vision that provides a sense of shared experience and shared future. In fact, the charismatics commitment to a future oriented vision appears to be the catalyst for Machiavellian behavior. Specifically, charismatics display Machiavellian behaviors with their willingness to opportunistically adapt their strategy for vision attainment (Fiol, Harris, \& House, 1999). Ideologues, in contrast, use an emotionally evocative, tradition-oriented vision that places an emphasis on a shared collective past and the values and standards necessary for a just society. Although the ideologues commitment to their vision is no less strong than that of the charismatics, there remains some 
question as to whether they will engage in Machiavellian behaviors to the same extent. Specifically, it seems possible that the ideologue's sense of values and commitment to justness may preclude them from engaging in Machiavellian behaviors. Pragmatics, on the other hand, do not articulate a vision for their followers. In fact, pragmatics are functional problem solvers that purely focus on the problem and need for solution (Mumford, in press). Even though the pragmatic leader is not committed to a vision, they are committed to problem solution. In fact, the pragmatic's willingness to manipulate situations to bring about efficient practical solutions is the strongest indicator of the pragmatic's engagement in Machiavellian behavior. Although these suppositions are theoretically based, there has been little empirical research regarding these three leader types, and even less investigating the role of Machiavellianism. Thus, it appears relevant to empirically examine the relationship between Machiavellianism and these alternative forms of leadership.

The primary purpose of this investigation was to empirically assess, via the historiometric approach, the relationship between Machiavellianism and a new taxonomy of outstanding leadership comprised of charismatic, ideological, and pragmatic leaders. Secondly, we set out to examine the relationship between Machiavellianism and leader orientation, being socialized or personalized. Finally, an attempt was made to assess the relationship between Machiavellianism and performance.

\section{Types of Outstanding Leaders}

Due to the substantial impact outstanding leaders have on the development and maintenance of high performing organizations, researchers have continued to examine the behaviors, skills, and characteristics outstanding leaders exhibit. However, the study of outstanding leaders stands as a difficult task given outstanding leaders' rare occurrence as well as their high-level commitments and busy schedules. Despite the difficulties, researchers have made notable progress with regard to our understanding of outstanding leadership, especially charismatic and transformational leadership (e.g., Conger \& Kanungo, 1998; House, 1995). Although theories of charismatic and transformational leadership evidence some noteworthy differences, they are both generally viewed as emerging from a single pathway (Bass, 1985; Conger \& Kanungo, 1998; Shamir, House, \& Arthur, 1993). Both are based on the proposition that outstanding leadership is dependent on the leader's effective articulation of an emotionally evocative, future oriented vision (Conger \& Kanungo, 1988; 1998; Deluga, 2001; House, 1995; Shamir, House, \& Arthur, 1993). Although theories of charismatic and transformational leadership have stood as relatively dominant theories of leadership (Hunt, 1999), Mumford, Strange, and Bedell (in press) have recently explored the existence of at least two alternative forms of outstanding leadership (i.e., ideological and pragmatic leadership). Mumford proposed that vision is not, directly, the basis for outstanding leadership but rather that the emergence of outstanding leaders is due to the leader's ability to make sense of a crisis through their prescriptive mental models (Drazin, Glynn, \& Kazanjian, 1999; Hunt, Boal, \& Dodge, 1999; Weick, 1995). Given that leadership is derived from the ability to help people make sense of and respond to a crisis situation (Drazin et al., 1999), it seems intuitive that different types of outstanding leadership arise from the different situations leaders use in sense-making (Weick, 1995). Using this logic, Mumford, Strange, and Bedell (in press) proposed a new taxonomy indicating at least three distinct, alternative pathways to outstanding leadership. The proposed taxonomy has been supported by a number of empirical investigations (Mumford, in press) examining behavioral and experiential differences. These findings indicate that charismatic, ideological, and pragmatic leaders represent distinct pathways to outstanding leadership.

\section{Charismatic Leadership}

Weber (1924) first outlined the theory of charismatic leadership to account for the remarkable impact outstanding leaders have on their followers. According to Weber (1947), charisma is characterized by five components: (a) the leader has extraordinary gifts, (b) there is a social crisis, (c) the leader provides a vision 
with a solution to the crisis, (d) the leader attracts followers with their vision, and (e) the leader confirms his giftedness with repeated success (Yukl, 2001). More recently, theorists have further defined the concept of charismatic leadership and examined the impact such leadership has on their followers, organizations, and social systems (e.g., Bass, 1985; Bass \& Avolio, 1994; House \& Howell, 1992; Yukl, 2001). Although "neocharismatic" theorists incorporate some of Weber's ideas, they have, in some ways, departed from his initial conception of charismatic leadership. Despite their differences, however, most theorists agree that the defining characteristic of charismatic leaders is their articulation of a future oriented, emotionally evocative vision (Conger \& Kanungo, 1988; 1998; Deluga, 2001; House, 1995; Shamir et al., 1993). A charismatic vision has three attributes that make it a powerful stimulus. First, it provides followers with an understanding of the crisis at hand and establishes a sense of identity (Meindl, 1990; Shamir, Zakay, Breinin, \& Popper, 1998). Second, it creates the sense of shared experiences and a shared future (Klein \& House, 1998). Third, it provides followers a path to resolution of the crisis and enables followers to make decisions consistent with the vision (Jacobsen \& House, 2001). Although a charismatic vision has the potential for substantial impact, Mumford contends that an understanding of leaders' vision is not sufficient for fully understanding outstanding leaders. Rather, he proposes that the articulation of a future-oriented vision is merely one, of several, ways of using a prescriptive mental model to exercise influence (Mumford, Strange, \& Hunter, in press).

\section{Ideological Leadership}

Weber (1924) also outlined two other pathways to outstanding leadership, the ideological and pragmatic paths. A few scholars (Gerring, 1997; Mills, 1967; Rejai, 1991) have extended Weber's observations regarding the nature and significance of ideological leadership, but the research has been limited, at best. Recently, Strange and Mumford (2002) further examined the nature of ideological leadership in an historiometric study of 60 historically notable leaders classified as charismatic (Winston Churchill), ideological (Ronald Reagan), or mixed (Emma Goldman). Using this approach, judges were asked to review the leader behaviors present in the chapters of interest and indicate whether they reflected one of 30 charismatic behaviors (e.g., the leader acted according to a vision that specifies a better future) or 29 ideological behaviors (e.g., the leader has a limited set of extreme, consistent, strongly held beliefs). The findings indicate that charismatic, ideological, and mixed type leaders can be distinguished from each other based on the frequency with which they express the aforementioned behaviors, especially with regard to behaviors indicative of value commitment and value autonomy. In fact, Strange and Mumford (2002) conclude, that, ideological leadership represents an alternative form of vision-based leadership. Unlike charismatic leaders, however, ideological leaders do not articulate a future-oriented vision. Instead, ideological leaders articulate an emotionally evocative vision that appeals to traditional virtues. This ideological vision is often framed in terms of the values and standards necessary for a just society. Consistent with Mumford's proposed taxonomy, the ideological leader's prescriptive mental models can also be used to exercise influence by constructing a vision that re-establishes a shared collective past through a shared set of beliefs and values (Mumford, Strange, \& Bedell, in press).

\section{Pragmatic Leadership}

The pragmatic or bureaucratic leader (Weber, 1924) represents a form of leadership that can be distinguished from both charismatic and ideological leadership because it does not involve the articulation of a vision. According to Mumford and Van Doorn (2001), pragmatic leaders exert their influence through an in depth understanding and sensitivity to the social system and the causal variables operating. This knowledge and sensitivity to practical problems causes pragmatic leaders to actively search for solutions to problems. In contrast to charismatic and ideological leaders, the pragmatic leader's appeal for support will focus on the problem and the need for a solution. Given the pragmatic 
leader's functional problem-focused approach, followers have less investment in the leader as a person or as a source of identity (Mumford, in press). Not surprisingly, pragmatic leaders are less likely than charismatic leaders to evoke strong affective reactions from their followers (Bass, 1990). Moreover, given their inability to affectively motivate followers (Shamir et al., 1993), pragmatic leaders appeal to the functional needs of followers rather than the promise of a better future. In fact, pragmatic leaders are notoriously skilled at using their expertise to devise actions that allow them to manipulate the current situation in a manner that brings about efficient practical solutions to the crisis at hand. Within this framework, it seems reasonable that pragmatic leaders exercise exceptional influence by using expertise and prescriptive models to resolve the problems brought on by a crisis (Mumford, Strange, \& Hunter, in press).

Given the cognitively and behaviorally distinctive pathways charismatic, ideological, and pragmatic leaders evidence, it is important to note an additional leadership categorization: orientation. More specifically, all leaders are oriented to using their power and influence for either good or bad.

\section{Socialized and Personalized Leaders}

Although outstanding leaders are masters of influence, their influence is not necessarily positive. Potentially, outstanding leaders can be a force for evil (witness Adolf Hitler) as well as a force for good (witness Jane Addams) (Beyer, 1999; Yukl, 1999). In an examination of direction of influence and the impact of outstanding leaders on society, House and Howell (1992) distinguished socialized from personalized leaders. Socialized leaders work towards enhancing others and the broader social system by training others with capabilities that transcend the leader. Personalized leaders, conversely, tend to be self-aggrandizing and seek to enhance their power and control regardless of the cost to others and the broader social system.

In another study investigating the distinction drawn between socialized leaders (e.g., Franklin Roosevelt) and personalized leaders (e.g., Adolf Hitler), O'Connor, Mumford, Clifton, Gessner, and Connelly
(1995) examined 80 historically notable $20^{\text {th }}$ century leaders. Using academic biographies, they content coded the "rise to power" chapters to assess the expression of characteristics such as narcissism, fear, outcome uncertainty, power motives, object beliefs, and negative life themes that are proposed to distinguish socialized and personalized leaders. They then analyzed the "summary" chapters to assess the overall leader performance outcomes. The results indicated that socialized and personalized leaders could be distinguished based on the leader's differential expression of these characteristics. It was found that leaders expressing personalized characteristics such as narcissism often had a negative impact on society.

In an extension of this study, Mumford, Strange, Gaddis, Licuanan, and Scott (in press) examined 120 historically notable $20^{\text {th }}$ century leaders classified by type (charismatic, ideological, pragmatic) and orientation (socialized, personalized). They examined the "summary" chapters to assess the overall leader performance outcomes. The findings indicated that the distinction between socialized and personalized could be applied to charismatic, ideological, and pragmatic leaders. Specifically, socialized and personalized leaders appear to look at different crises and pursue different goals in their decision-making. For instance, socialized leaders apply a longer timeframe and more accurately identify critical issues. The evidence of critical performance differences between socialized and personalized leaders indicates that integrity is a critical determinant of performance with respect to the long-term outcomes associated with outstanding leaders. Given the evidence available, it seems reasonable to argue that there is a distinction between personalized and socialized leaders that can be applied to the different types of outstanding leaders (i.e., personalized charismatic, socialized charismatic, personalized ideologue, socialized ideologue, personalized pragmatic, and socialized pragmatic ). In other words, by further classifying the leaders by type and orientation, researchers can gain a better understanding of the amount of Machiavellian behavior differentially attributable to type and orientation. 


\section{Machiavellianism}

The pursuit and skillful use of power has been considered fundamental to effective leadership by a number of observers (Bass, 1990). One such observer, Nicolo Machiavelli remains a prominent theoretician in modern political theory (Fleisher, 1972; Mansfield, 1996). Machiavelli (1513/1966) advocates a number of behaviors necessary for acquiring and maintaining power in socially competitive situations, specifically, mistrust in human nature, lack of conventional morality, opportunism, and lack of affect in interpersonal relationships. Accordingly, a leader needs an analytical attitude without a sense of shame or guilt (Deluga, 2001) and must be willing to engage in manipulative, exploitive, and deceitful behavior. For the Machiavellian individual, "the ends justify the means" (Deluga, 2001, p. 341).

Given these strong behavioral descriptors, Christie (1970) developed a scale of Machiavellianism using statements from The Prince and The Discourses. The Mach scale measures the extent to which respondents agree with Machiavelli's statements regarding how a leader attempting to obtain and maintain power and influence should act toward others. Empirical investigations using the Mach scale indicate a number of differences between high Machs and low Machs. Individuals exhibiting high levels of Machiavellianism tend to resist social influence, are amoral in controlling personal interactions, endeavor to personally control situations, and display a lack of affect in their interactions (Christie \& Geis, 1970a; Drory \& Gluskinos, 1980; Fehr, Samsom, \& Paulhus, 1992; Geis, 1978; Wilson, Near, \& Miller, 1996). Furthermore, high Machs are convincing liars (DePaulo \& Rosenthal, 1979; Lewicki, 1983) and use deceptive interpersonal tactics (Shapiro, Lewicki, \& Devine, 1995). Individuals exhibiting low levels of Machiavellianism appear to be less effective at manipulation and are more personally and affectively involved than high Machs. Specifically, in face-to-face situations, low Machs tend to be empathizing, involved, and distractible, whereas high Machs tend to be objective, unflustered, and in control (Geis, 1978).
Although these findings seem condemnatory of high Machs, there is a brighter side to their behaviors. Recent research indicates that high Machs may not be more hostile, vicious, vindictive (Wrightsman, 1991), or manipulative (Shepperd \& Socherman, 1997) than low Machs. Apparently, high Machs function most effectively in stressful, unstructured, and face-to- face competitive situations where their lack of affect and openness to improvisation are advantageous (Christie \& Geis, 1970a). For instance, Machiavellian leaders are able to portray an image of confidence, even when they are uncertain (Martin \& Sims, 1956; Pfiffner, 1951) and have an opportunistic sense of timing in social interactions especially when forming political alliances with those who have power to promote and protect their self interests (Christie \& Geis, 1970a). Consistent with this observation, Simonton (1986) reported that Presidential Machiavellianism was positively associated with the total number of legislative acts passed as well as the number of legislative victories and defeats. Furthermore, Deluga (2001) found that Presidential Machiavellianism was positively related to rated performance and charismatic leadership.

Although Machiavelli's principles are often viewed with pejorative connotations regarding manipulation and deceit, there may be a bright side to Machiavellianism since it is seen across social statuses (Christie \& Geis, 1970a). In fact, the actual use of Machiavellian tactics is proposed to be more widespread than acknowledged (Bass, 1990). Given the Machiavellian attributes of "coolness under pressure," lack of distraction by interpersonal concerns, emotional issues, or social influences (Deluga, 2001), Machiavellian leaders are able to devote full attention to cognitive analysis of the situation and develop competitively advantageous strategies for winning (Christie \& Geis, 1970a). Related to leadership, Machiavellianism may be seen as an asset to those in high-level leadership positions, especially historically notable leaders. Interestingly, a number of researchers have examined the relationship between charismatic leadership and Machiavellianism (Deluga, 2001; Gardner \& Avolio, 1995; House \& Howell, 
1992) and found them to be positively related. However, there has been no investigation of Machiavellianism in relation to other forms of outstanding leadership, specifically ideological and pragmatic leadership. Although the present study is exploratory in nature, it does seem reasonable to assume that the three leader types will differentially exhibit Machiavellian behavior. Specifically, one might expect ideological leaders to express a limited number of Machiavellian behaviors given their strong sense of morality and commitment to a given value system. It seems reasonable to suggest that engaging in Machiavellian behaviors such as mistrust in human nature, lack of conventional morality, sense of opportunism, or lack of genuine concern would undermine their method of influence. In contrast, pragmatic leaders may engage in more Machiavellian behaviors given their problem-focused approach. Pragmatic leaders are theorized to be unconstrained by a moral system and are willing to manipulate others to achieve their objectives. Given the cognitive and behavioral differences amongst the three leader types, it is reasonable to assume that the leaders will differentially express Machiavellian behavior. It is unclear, however, what the relationship among the three leader types will be.

Hypothesis 1: Charismatic, ideological, and pragmatic leaders will differentially express Machiavellian behavior.

Additionally, given that socialized leaders work towards enhancing others and the broader social system while personalized leaders tend to be self-aggrandizing and seek to enhance their power and control regardless of the cost to others and the broader social system it seems reasonable to anticipate that personalized leaders will act in a more Machiavellian fashion than socialized leaders. Specifically, personalized leaders appear less morally constrained and are more likely to engage in any political behavior that would enhance their power. Their willingness to acquire and maintain power at the expense of others makes personalized leaders especially susceptible to engaging in a large number and variety of Machiavellian behaviors.

Hypothesis 2: Personalized leaders will exhibit a higher number of Machiavellian behaviors than socialized leaders.
Finally, in an experimental study done by Drory and Gluskinos (1980), groups led by high Machs did not differ in overall productivity. More recently, however, Simonton (1986) found that Machiavellian presidents were the most successful in terms of legislative behavior and Deluga (2001) found that Machiavellianism was positively related to rated performance. Although there is early conflicting evidence regarding the relationship between Machiavellianism and performance, the most recent research suggests that these findings should generalize and Machiavellianism will, overall, be positively related to performance across the different leader types.

Hypothesis 3: High levels of Machiavellianism in outstanding leaders will be positively related to performance.

\section{Method}

The present study utilizes the historiometric approach for assessing outstanding leadership. The historiometric approach is a unique combination of both quantitative and qualitative approaches that enables the quantitative analysis of multiple cases. Specifically, qualitative historic records are selected and coded using rating scales to enable quantitative analysis. Although, historic records have been used to code very concrete objective behaviors such as time of event, historic records have also been used to assess unobservable variables such as motives (Winter, 1987) and personality characteristics (Deluga, 2001; Simonton, 1984, 1986, 1999). The present study implements this approach using "summary" chapters of academic biographies to assess performance and leader communications in the "pinnacle of power" chapters of academic biographies to assess Machiavellianism in outstanding leaders.

\section{Sample and Data Sources}

The 120 historically notable leaders assessed in this study are identical to those selected in the initial comparison studies of charismatic, ideological, and pragmatic leadership (Mumford, in press). The sample was selected for both type (charismatic, ideological, pragmatic) and orientation (socialized, personalized) resulting in 20 leaders per cell. 
Leaders were included in the study only if they had achieved positions of power in the $20^{\text {th }}$ century and at least one factually based academic biography was available describing the leader's career (see Appendix). In an effort to improve generalizeability, an attempt was made to sample both western and non-western leaders as well as men and women. In addition, leaders were selected across different fields (e.g., military, business, religious, political), however there was no attempt at equal representation given the tendency of different leader types to gravitate to certain fields (Mumford, in press).

The historic data used in this study is consistent with the data used in a series of studies by Mumford (in press). The historic data was selected from highly structured academic biographies that described the careers of the selected leaders. Mumford, Gaddis, Strange, and Scott (in press) developed five criteria for selecting the best biography: 1) did the biography stress accurate and detailed reporting of the leader's behavior and key events he or she encountered over the course of his or her career? 2) did the biography expressly focus on behaviors of concern with respect to the present set of investigations (e.g., leader-follower interactions, communication strategies, etc.)? 3) did the biography provide a reasonably detailed account of the leader's early life? 4) did the biography provide a clear and reasonably objective summary of the leader's accomplishments? and 5) was there evidence of adequate scholarly work as indicated by citations provided and sources examined? The final biography list Mumford, Gaddis, Strange, \& Scott (in press) identified consisted of biographies that best satisfied the five criteria.

A number of criteria were used to assign outstanding leaders to each type and orientation classification. Charismatic leaders were identified by applying the criteria that they articulated a future-oriented vision involving change (Conger \& Kanungo, 1998; Shamir et al., 1993). Ideological leaders were identified by applying the criteria that they articulated a vision based on strongly held personal values (Strange \& Mumford, 2002). Pragmatic leaders were identified by applying the criteria that leaders engage in analytical problem-solving to resolve crises (Mumford \& Van Doorn, 2001). The orientation of a leader was determined using the criteria that socialized leaders initiate action for the betterment of people, society, or institutions regardless of personal consequences while personalized leaders initiate action to acquire, maintain, and enhance power (O'Connor et al., 1995). Table 1 presents the list of leaders included in this sample.

\section{Measures and Procedures}

The 20-item Machiavellianism IV Scale (Mach IV; Christie, 1970) was used to assess Machiavellianism of the aforementioned 120 outstanding leaders. The Mach IV measures respondents' agreement with Machiavellian beliefs on 7-point scales in Likert format $(1=$ strongly disagree and $7=$ strongly agree). The items were developed to be theoretically congruent with statements from Machiavelli (1513/1966) in The Prince and The Discourses. The items measure the use of manipulative interpersonal tactics such as flattery and deceit as well as cynical and traditionally immoral viewpoints (McHoskey, 1995). Although the Mach IV has suffered some criticism, it remains the most widely used measure of Machiavellianism and consistently exhibits acceptable psychometric properties (McHoskey, Worzel, \& Szyarto, 1998). In the present study, the wording of items was adjusted for rating purposes. For example, an item previously worded as "The best way to handle people is to tell them what they want to hear," was changed to "To what extent does the leader communicate that the best way to handle people is to tell them what they want to hear."

Although Deluga (2001) examined presidential Machiavellianism using profiles, the present study attempts to assess Machiavellianism of outstanding leaders using their own communications. A number of researchers have used leader speeches to assess the personality characteristics of American presidents (e.g., Evered, 1983; Hantz, 1996; Suedfeld \& Wallace, 1995; Winter, 1987; Zullow, Oettingen, Peterson, \& Seligman, 1988). However, Sigelman (2002) notes the potential problem of presidential addresses being drafted by ghostwriters. In an effort to control 
Table 1:

Classification of Leaders by Type and Orientations

\begin{tabular}{|c|c|c|c|}
\hline & \multicolumn{3}{|c|}{ Type } \\
\hline Orientation & Ideological & Charismatic & Pragmatic \\
\hline Socialized & $\begin{array}{l}\text { 1. Jane Addams } \\
\text { 2. Susan B. Anthony } \\
\text { 3. Dietrich Bonhoeffer } \\
\text { 4. Michael Collins } \\
\text { 5. Eugene V. Debs } \\
\text { 6. John Dewey } \\
\text { 7. W.E.B. du Bois } \\
\text { 8. Betty Friedan } \\
\text { 9. Indira Gandhi } \\
\text { 10. Mohandas Gandhi } \\
\text { 11. Charles de Gaulle } \\
\text { 12. Emma Goldman } \\
\text { 13. Dag Hammarskold } \\
\text { 14. John L. Lewis } \\
\text { 15. Kwame Nkrumah } \\
\text { 16. Ronald W. Reagan } \\
\text { 17. Eleanor A. Roosevelt } \\
\text { 18. Theodore Roosevelt } \\
\text { 19. Lech Walesa } \\
\text { 20. Woodrow T. Wilson } \\
\end{array}$ & $\begin{array}{l}\text { 1. Mustafa K. Ataturk } \\
\text { 2. David Ben-Gurion } \\
\text { 3. Cesar Chavez } \\
\text { 4. Winston Churchill } \\
\text { 5. Henry Ford } \\
\text { 6. Samual Gompers } \\
\text { 7. Lee Iacocca } \\
\text { 8. John F. Kennedy } \\
\text { 9. Jomo Kenyatta } \\
\text { 10. Martin Luther King, Jr. } \\
\text { 11. Fiorello H. LaGuardia } \\
\text { 12. Douglas MacArthur } \\
\text { 13. Louis B. Mayer } \\
\text { 14. J.P. Morgan } \\
\text { 15. Edward R. Murrow } \\
\text { 16. Gamal Abdel Nasser } \\
\text { 17. Sam Rayburn } \\
\text { 18. Franklin D. Roosevelt } \\
\text { 19. Anwar Sadat } \\
\text { 20. Margaret Thatcher } \\
\end{array}$ & $\begin{array}{l}\text { 1. Warren Buffet } \\
\text { 2. Richard Daley } \\
\text { 3. Walt Disney } \\
\text { 4. John Foster Dulles } \\
\text { 5. Alfred Dupont } \\
\text { 6. Dwight D. Eisenhower } \\
\text { 7. Felix Frankfurter } \\
\text { 8. Berry Gordy } \\
\text { 9. Katharine Graham } \\
\text { 10. Oliver W. Holmes } \\
\text { 11. George Marshall } \\
\text { 12. Mikail Gorbechev } \\
\text { 13. Thomas Watson } \\
\text { 14. George H. Rickover } \\
\text { 15. Erwin Rommel } \\
\text { 16. George Soros } \\
\text { 17. Josip B. Tito } \\
\text { 18. Harry S. Truman } \\
\text { 19. Sam Walton } \\
\text { 20. Booker T. Washington } \\
\end{array}$ \\
\hline Personalized & $\begin{array}{l}\text { 1. Lavrenti Beria } \\
\text { 2. Fidel Castro } \\
\text { 3. Georges Clemenceau } \\
\text { 4. Ferdinand Foch } \\
\text { 5. Francisco Franco } \\
\text { 6. Marcus Garvey } \\
\text { 7. Warren Harding } \\
\text { 8. Rudolf Hess } \\
\text { 9. Heinrich Himmler } \\
\text { 10. Ho Chi Minh } \\
\text { 11. Vladimir Lenin } \\
\text { 12. Joe McCarthy } \\
\text { 13. Pol Pot } \\
\text { 14. John D. Rockefeller } \\
\text { 15. Josef Stalin } \\
\text { 16. Leon Trotsky } \\
\text { 17. Kaiser Wilhelm II } \\
\text { 18. Deng Xiaoping } \\
\text { 19. Emiliano Zapata } \\
\text { 20. Mao Ze-dong } \\
\end{array}$ & $\begin{array}{l}\text { 1. Idi Amin } \\
\text { 2. Neville Chamberlain } \\
\text { 3. John Delorean } \\
\text { 4. Porfirio Diaz } \\
\text { 5. Francois Duvalier } \\
\text { 6. Hermann Goring } \\
\text { 7. Assad Hafaz } \\
\text { 8. Adolf Hitler } \\
\text { 9. Jimmy Hoffa } \\
\text { 10. Herbert R. Hoover } \\
\text { 11. J. Edgar Hoover } \\
\text { 12. Huey P. Long } \\
\text { 13. Ferdinand Marcos } \\
\text { 14. Benito Mussolini } \\
\text { 15. Manuel Noriega } \\
\text { 16. Eva Peron } \\
\text { 17. Juan Peron } \\
\text { 18. Rafael Trujillo } \\
\text { 19. W. C. Westmoreland } \\
\text { 20. Malcolm X } \\
\end{array}$ & $\begin{array}{l}\text { 1. Al Capone } \\
\text { 2. Andrew Carnagie } \\
\text { 3. Otis Chandler } \\
\text { 4. Lyndon B. Johnson } \\
\text { 5. Al Dunlap } \\
\text { 6. Henry Ford II } \\
\text { 7. Carlo Gambino } \\
\text { 8. Leslie Groves } \\
\text { 9. Leona Helmsley } \\
\text { 10. Reinhard Heydrich } \\
\text { 11. Horatio Kitchener } \\
\text { 12. Alfreid Krupp } \\
\text { 13. Robert Moses } \\
\text { 14. Rupert Murdoch } \\
\text { 15. George Patton } \\
\text { 16. Jackie Presser } \\
\text { 17. Richard M. Nixon } \\
\text { 18. David Sarnoff } \\
\text { 19. Martha Stewart } \\
\text { 20. Lew Wasserman }\end{array}$ \\
\hline
\end{tabular}

for this potential problem, the communications selected for assessment include verbatim communications with varying levels of formality (i.e., written communications, personal communications, formal speeches, impromptu speeches). Another concern of researchers is that the subtle and deceptive nature of Machiavellianism makes observer judgments difficult (Deluga, 2001), however, a number of researchers have demonstrated that observers 
can accurately classify levels of Machiavellianism (e.g., Deluga, 2001; Geis \& Levy, 1970; Geis, Christie, \& Nelson, 1970). In an effort to further reduce this concern, the present study assessed leader communications in context. By examining the context, the three sentences preceding and following the communication, raters were better able to assess the potentially subtle deception characteristic of Machiavellian individuals.

Assessment of Machiavellianism using the academic biographies began with the identification of two or three "pinnacle of power" chapters. "Pinnacle of power" chapters were used to sample leader communications based on the proposition that communications given during this period would best represent the prototypic characteristics of outstanding leaders. Typically, 6 to 10 noteworthy communications were identified in the "pinnacle of power" chapters with the associated material describing the context of the communication (i.e., three sentences prior to communication and three sentences following the communication). Typically, the selected material averaged 3 to 4 pages in length. Although it could be argued that failure to remove leader identifiers has the potential to result in rater bias, a pretested sample indicated no difference in ratings between those with and without leader identifiers. Thus, in preparing the data, leader identifiers were not removed. See Figure 1 for communication excerpts.

In evaluating the leader communications presented in the "pinnacle of power" chapter, four judges were asked to evaluate the material using the adjusted Mach IV scale. For each item on the adjusted Mach IV scale, the judge was asked to rate to what extent does the leader communicate the particular item of interest (e.g., To what extent does the leader communicate that honesty is the best policy?). Before making the ratings, the four judges, all doctoral candidates in industrial and organizational psychology, were exposed to a 25 hour training program. In this training program, the judges were familiarized with the Mach IV items and example communications. Subsequently, judges practiced applying the rating scales to a set of sample communications drawn from five different biographies. Judges met to discuss their ratings and clarify any disagreements. Application of these procedures resulted in an adequate interrater agreement coefficient. Thus, the reliable assessment of Machiavellianism in leader communications was sought using the aforementioned procedures.

\section{Performance}

Although prior studies have found that charismatic, ideological, and pragmatic leaders do not differ on overall performance (Mumford, in press), studies contrasting socialized and personalized leaders have indicated marked performance differences (Mumford, in press; O'Connor et al., 1995). To examine differences in performance, especially with respect to Machiavellianism, the performance data used by Mumford, Strange, Gaddis, Licuanan, and Scott (in press) was requested. Thus the performance criteria or outcome measures of the outstanding leaders were assessed by a separate and independent panel of trained psychologists. Assessments were made using the prologue and epilogue chapters presented in the various biographies under consideration.

Consistent with prior research (Mumford, in press; Strange \& Mumford, 2002), twelve general criterion measures were drawn from the summary chapters to assess overall appraisal of performance with respect to impact. The first five criterion were counts based on the biographer's observations regarding: 1) the number of positive contributions made by the leader, 2) the number of negative contributions made by the leader, 3 ) the number of different types of positive contributions made by the leader, 4) the number of different types of negative contributions made by the leader, and 5) the number of institutions established by the leader. In addition to these counts, the performance rating psychologists rated seven criteria based on the material presented in the "summary" chapters. These ratings were made on a 5-point scale and examined: 6) how much did the leader contribute to society? 7) how long did these contributions last? 8) how many people did the leader affect? 9) did the leader initiate 
Figure 1: Speech abstracts for a high mach and low mach leader

High mach

\section{Adolf Hitler}

"I am asking of no German man more than I myself was ready to perform during the four years of World War I. The German people will suffer no hardships which I do not suffer. My whole life henceforth belongs more than ever to my people. I am from now on nothing more than the first soldier of the Reich. I have once more put on the coat that was most sacred and dear to me. I will not take it off again until victory is assured, or I will not survive the outcome."

From Payne. (1973, p. 364)

Low mach

\section{Martin Luther King Jr.}

"Certainly the Negro has been deprived. Few people consider the fact that, in addition to being enslaved for two centuries, the Negro was, during all these years, robbed of the wages of his toil. No amount of gold could provide an adequate compensation for the exploitation and humiliation of the Negro in America down through the centuries. Not all the wealth of this affluent society could meet the bill. Yet, a price can be placed on unpaid wages. The ancient common law has always provided a remedy for the appropriation of the labor of one human being by another. This law should be made to apply for American Negroes. The payment should be in the form of a massive program by the government of special, compensatory measures which could be regarded as a settlement in accordance with the accepted practice of common law. Such measures would certainly be less expensive than any computation based on two centuries of unpaid wages and accumulated interest.

I am proposing, therefore, that, just as we granted a GI Bill of Rights to war veterans, America launch a broadbased and gigantic Bill of Rights for the Disadvantaged, our veterans of the long siege of denial. I am specifically proposing that the platform of [this] party include an endorsement and support for the broad plan of such a Bill.

A Bill of Rights for the Disadvantaged would immediately transform the conditions of Negro life. The most profound alteration would not reside so much in the specific grants as in the basic psychological and motivational transformation of the Negro. I would challenge skeptics to give such a bold new approach a test for the next decade. I contend that the decline in school dropouts, family breakups, crime rates, illegitimacy, swollen relief rolls and other social evils would stagger the imagination. Change in human psychology is normally a slow process, but it is safe to predict that, when a people is ready for change as the Negro has shown himself ready today, the response is bound to be rapid and constructive."

From Bennett. (1976, p. 218-219)

mass movements? 10) did the leader have a vision that was maintained after they left power? 11) were institutions established by the leader still in existence? and 12) how favorably did the author view the leader? The interrater agreement coefficient was .83 (Mumford, Gaddis, Strange, \& Scott, in press).

\section{Controls}

Consistent with the original studies assessing charismatic, ideological, and pragmatic leadership (Mumford, in press), a number of control measures were used. In an attempt to account for temporal, cultural, and historic effects, the four judges for this study made assessments using a set of evaluations: 1) was the leader a pre- or post-World War II leader? 2) was the leader from a western or nonwestern country? 3) was the leader's country industrialized or non-industrialized? and 4) was the leader's biography translated into English? In addition, the raters made assessments on the leader's role and attributes: 1) type of leadership role (e.g., business, political, nonprofit organization, military), 2) level of political conflict in the leader's organization, 3) years in 
power, and 4) elected or appointed versus leadership positions seized by force. To account for variables relevant to communication, the four judges also assessed: 1) total number of communications identified, 2) frequency of major communications during the period the leader was in power, 3) the amount of material quoted in the biography, 4) need for translation of communications, 5) amount of input others had in preparation of communications, and 6) size of the leader's audience.

\section{Results}

\section{Machiavellianism Scores}

The Machiavellianism scores of outstanding leaders were calculated by averaging the 20 items of the Mach IV with higher scores indicating higher levels of Machiavellianism and scores ranging, theoretically, from 1 to 7 . The reliability for the scale was acceptable $(\square=.92)$. Results revealed that Richard Nixon ( $\bar{X}=6.47$ ), Martha Stewart $(\bar{X}=6.15)$, Benito Mussolini $(\bar{X}=6.05)$, Adolf Hitler $(\bar{X}=5.75)$, and Fidel Castro $(\bar{X}$ $=5.70$ ) emerged as highest in Machiavellianism, whereas Martin Luther King, Jr. ( $\bar{X}=1.16)$, Dietrich Bonhoeffer $(\bar{X}=1.35)$, Mohandas Ghandi ( $\bar{X}=1.70)$, Jane Addams $(\bar{X}=1.90)$, and Lech Walesa $(\bar{X}=1.95)$ were rated lowest. Example communication excerpts for Adolf Hitler and Martin Luther King, Jr. can be seen in Figure 1. Using procedures put forth by Shrout and Fleiss (1979), interrater reliability was assessed and fell within acceptable ranges (ICC $=.73$ ).

\section{Hypotheses}

Hypothesis one predicted that charismatic, ideological, and pragmatic leaders would differentially express Machiavellian characteristics. And, similarly hypothesis two predicted that leaders with a personalized orientation would exhibit higher levels of Machiavellianism than socialized leaders. To assess if differences exist between leader types (charismatic, ideological, and pragmatic) and leader orientations (personalized and socialized) on scores of Machiavellianism, an ANCOVA was conducted. The results revealed a significant main effect for leader type (charismatic, ideological, and pragmatic), $F(2$, 106) $=7.65, p \leq .001$ and leader orientation (personalized and socialized), $F(1,106)=17.93$, $p \leq .001$. There was no significant interaction, $F(2,106)=.29, p \geq .05$. The significant main effects for type indicated that pragmatic leaders exhibited the highest level of Machiavellian characteristics $(\bar{X}=4.06 S E=.14)$ compared to charismatics ( $\bar{X}=3.57, S E=.14$ ) who were mid-level, and ideologues $(\bar{X}=3.26, S E=.14$ ) who were the lowest level Machs. Personalized leaders exhibited higher levels of Machiavellianism than socialized leaders $(\bar{X}=$ 4.00, $S E=.12$ versus $\bar{X}=3.25, S E=.12$ ). Thus, both hypothesis one and two were supported. Figure 2 depicts the results obtained in this analysis.

To address the third hypothesis, that high levels of Machiavellianism in outstanding leaders will be positively related to performance, a series of hierarchical regression analyses were conducted. In the first set of regression analyses, Mach scores were examined when controlling for relevant control variables only. In the second set of analyses, control variables as well as leader type and orientation were taken into account prior to adding Mach scores to the model. This second set of analyses allowed for the examination of (a) the extent to which Machiavellianism accounted for additional variance beyond leader type and orientation as well as, (b) a general comparison of standardized beta-weights to the first set of regression analyses where leader type and orientation were not taken into account.

To conduct the first set of regression analyses, significant control variables were added into the first block of the model, followed by the second block consisting of Mach scores only. These variables were regressed onto each of the 12 performance criteria. The results of these analyses can be seen in Table 2 . Overall, the results suggest that Machiavellianism was related to performance, but in the opposite direction hypothesized. More precisely, Machiavellianism scores were significantly negatively related to performance across 8 of the 
Figure 2:

Relationship between levels of Machiavellianism, leader type, and leader orientation

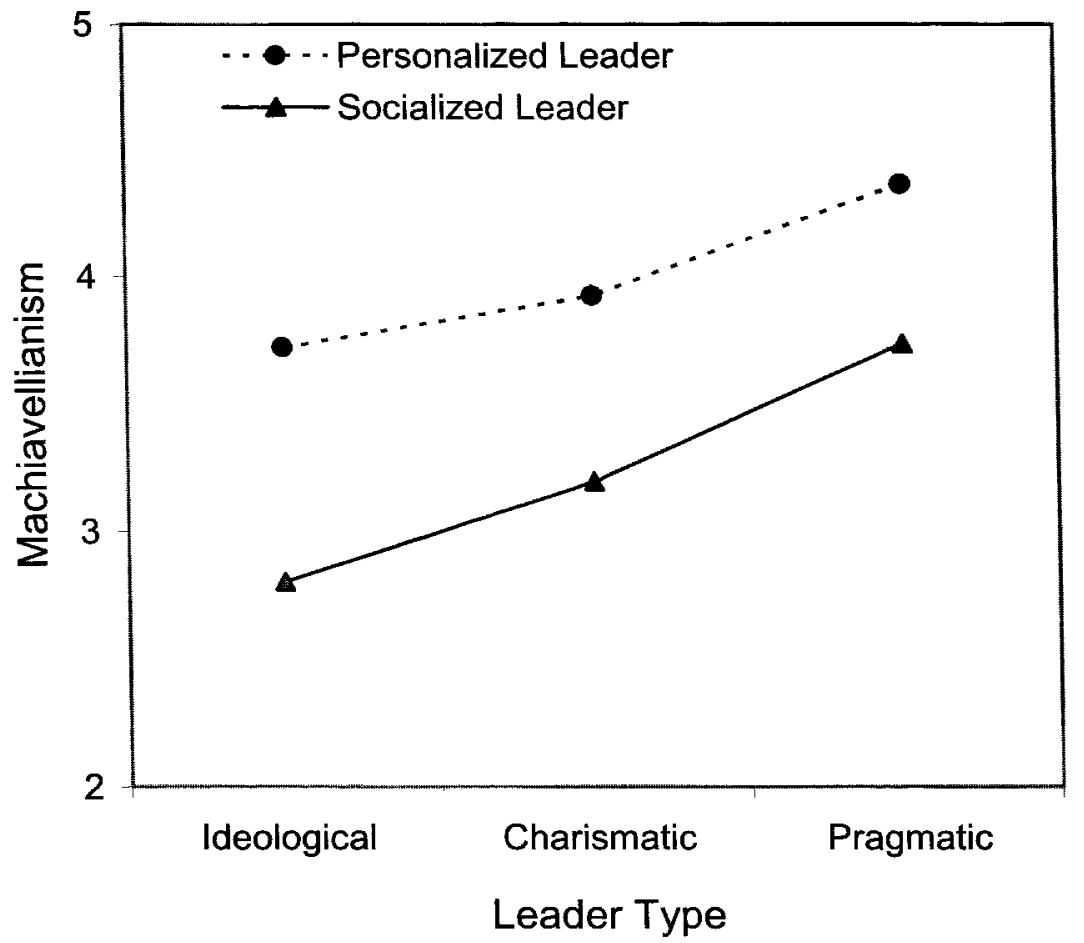

12 criteria. Note that, for two of the criteria, number of negative contributions and number of negative types of contributions there was a significant positive relationship. The nature of the variables, however, suggests a negative pattern with respect to performance - higher Mach scores were positively related to poor performance outcomes (i.e., undesirable outcomes) and as such, were viewed as negative relationships.

The second set of regression analyses began, similar to the first, with an initial block of significant control variables. The second block, however, differed from the above analysis in that leader type and orientation were added to the model. It is of note that, due to linear dependency, only two dummy-coded variables of leader type were included in the model.

Finally, in the third step, Machiavellian scores were added. The results of these analyses revealed that, when controlling for leader type and orientation, Machiavellianism was significantly related to performance across only 3 of the 12 performance criteria (see Table 3 ).
Moreover, a cursory comparison of the standardized beta weights from the first set of analyses suggests that when accounting for leader type and orientation there is a substantial drop in the magnitude of the relationship between Machiavellianism and performance. Thus, with respect to the specific hypothesis that Machiavellianism would be related to performance, the lack of positive relationships and a general lack of relationships overall suggests that hypothesis three was not supported.

In sum, the results suggest significant differences in Machiavellianism across the three leader types as well as the two leader orientations. Moreover, it appears that Machiavellianism, on the whole, is related to performance - though in the opposite direction anticipated. However, the magnitude and direction of the relationships appear relevant in spite of the unpredicted outcome. With respect to Machiavellianism and performance when accounting for leader type and orientation, the 


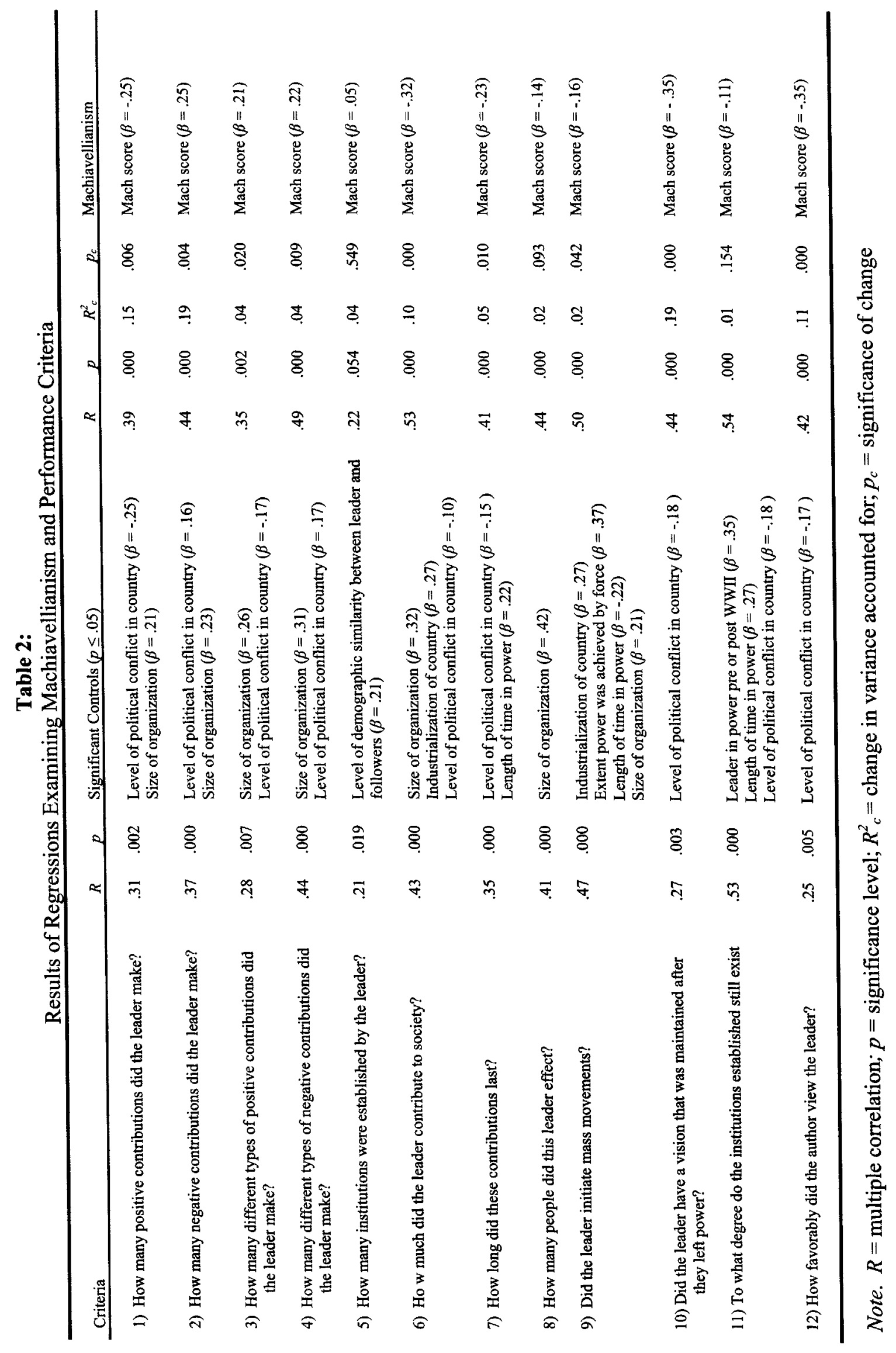




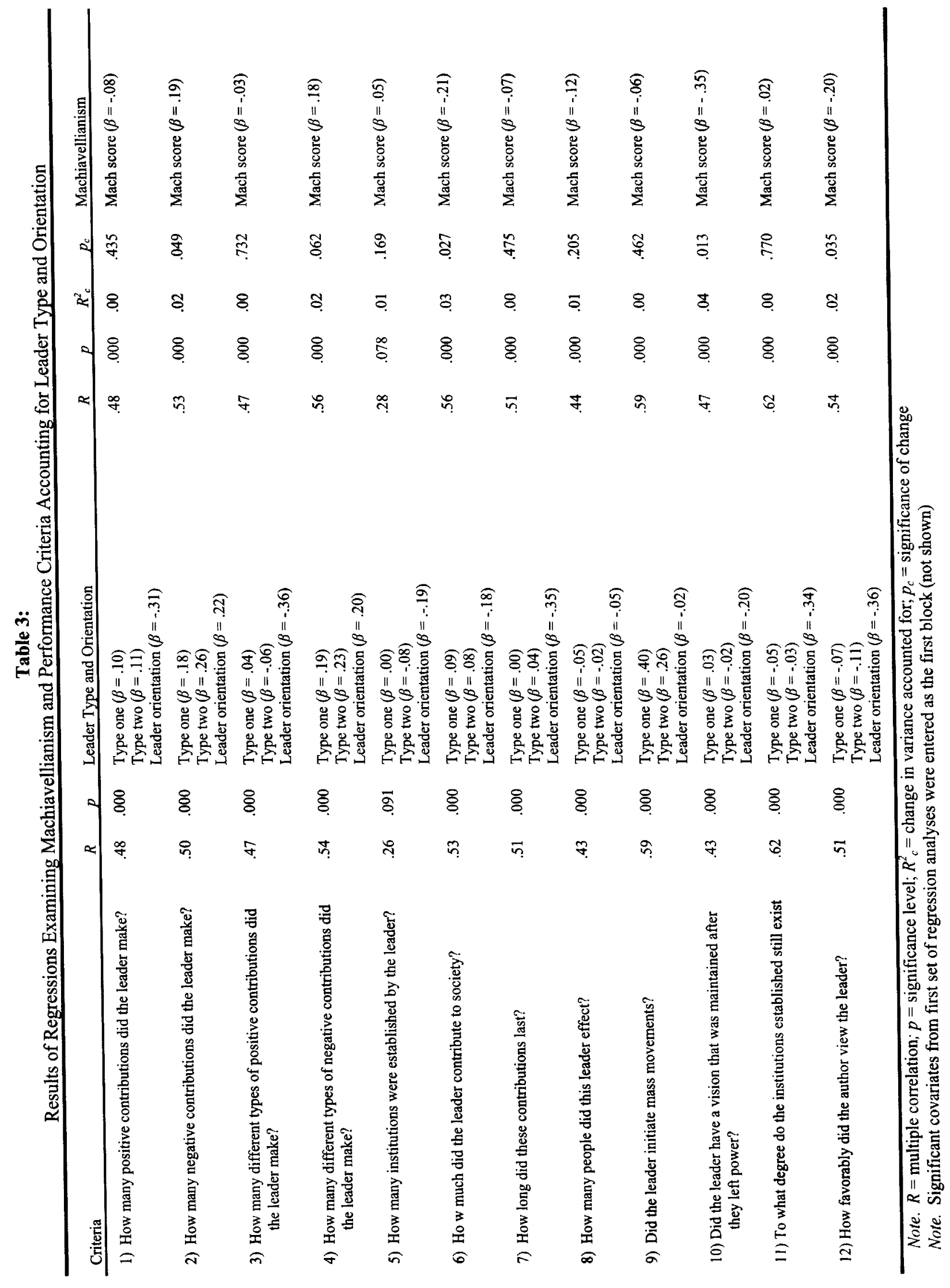


decreased magnitude of the relationships overall suggests that there may be overlap in the behaviors exhibited by charismatic, ideological, and pragmatic leader types with personalized and socialized orientations and leaders exhibiting Machiavellian characteristics.

\section{Discussion}

Before turning to the broader implications of the present effort, certain limitations should be noted. First, although 120 leaders is a relatively large data set compared to many historiometric studies (e.g., Deluga, 2001; Simonton, $1984 ; 1986 ; 1999)$, the fact remains that the sample was systematically sampled according to leader type and orientation. Therefore, the present study has little to say about alternative forms of leadership, for example, mixed type leaders - or leaders evidencing characteristics of both pragmatics and charismatics (Strange \& Mumford, 2002). Secondly, despite the widespread use of communications to assess personality characteristics (e.g., Evered, 1983; Hantz, 1996; Suedfeld \& Wallace, 1995; Winter, 1987; Zullow et al., 1988), there has been some concern regarding the impact of ghostwriters (Sigelman, 2002). What should be noted here, however, is that an extensive number of general and communication specific controls were applied in the present study to account for potential biases. Finally, in preparing the data, leader identifiers were not removed, though a pre-tested sample indicated no difference in ratings between those with and without leader identifiers. Even bearing these limitations in mind, we believe that the results obtained in the present study have some noteworthy implications for understanding the relationship between Machiavellianism and outstanding leadership. Specifically, the ANCOVA results indicate that charismatic, ideological, and pragmatic leaders differentially exhibit Machiavellian characteristics. Although past research has established a relationship between charismatic leaders and Machiavellianism (Deluga, 2001), the current findings indicate that relative to ideologues and pragmatics, charismatic leaders evidence moderate levels of Machiavellianism. Interestingly, pragmatic leaders evidenced the highest levels of Machiavellianism while ideologues evidenced the lowest levels. These findings can be understood in terms of the constraints imposed on each leader type by the characteristic ways in which they exercise influence. Ideological leaders, the lowest Machs, are theorized to exercise influence using an emotionally evocative vision that appeals to traditional virtues. In fact, the ideological vision is often framed in terms of a shared set of standards and values necessary for a just society (Mumford, Strange, \& Bedell, in press; Strange \& Mumford, 2002). Given the ideological leader's underlying sense of morality and strong commitment to a given value system and emotional attachment to others, they may be unable to engage in high levels of Machiavellian behavior. It is plausible to suggest that evidencing Machiavellian characteristics such as mistrust in human nature, lack of conventional morality, sense of opportunism, or lack of genuine concern for followers, would undermine the ideological leader's method of influence. Similarly, charismatics, the mid-level Machs, also exercise influence through a vision, an emotionally evocative, future-oriented vision (Conger \& Kanungo, 1988; 1998; Deluga, 2001; House, 1995; Shamir et al., 1993). This vision has three attributes that make it a powerful stimulus: 1) it provides followers with an understanding of the crisis at hand and establishes a sense of identity (Meindl, 1990; Shamir et al., 1998), 2) it creates a sense of shared experiences and a shared future (Klein \& House, 1998), and 3) it enables followers to make decisions consistent with the vision (Jacobsen \& House, 2001). Thus, the charismatic leader exercises influence by articulating an emotionally evocative, future oriented vision and creating a sense of shared experience and future. Although charismatic leaders maintain commitment to a vision, they can exhibit more Machiavellian characteristics than ideologues because their vision is not constrained by a strict belief and value system. Despite the charismatic leader's commitment to a vision, they are capable of opportunistically adapting their strategy for vision attainment (Fiol, Harris, \& House, 1999). Therefore, it seems reasonable to find that charismatic leaders 
exhibited higher levels of Machiavellianism than ideological leaders. In contrast to ideologues and charismatics, pragmatic leaders, the highest level Machs, do not have a vision. Rather, pragmatic leaders exert influence with an indepth understanding of the social system (Mumford, Strange, \& Bedell, in press). Pragmatics use a functional, problem-based approach that deals with present situations and demands. In fact, the "strength of pragmatic leaders is in their proficiency in devising actions that enable them to manipulate the current situations to bring about efficient and practical solutions" (Mumford, Strange, \& Bedell, in press, p. 12). Given these characteristics, it is not surprising that pragmatic leaders were the highest level Machs. Overall, characteristically of Machs, pragmatic leaders are not generally constrained by a moral system, interact nonaffectively with followers (Mumford, in press), and are willing to manipulate others to achieve their desired result. In sum, the findings indicate that different types of outstanding leaders, specifically, charismatic, ideological, and pragmatic leaders, differentially exhibit Machiavellian characteristics.

With regard to leader orientation, the ANCOVA results indicate that personalized leaders exhibit significantly stronger Machiavellian characteristics than socialized leaders. Personalized leaders tend to be selfaggrandizing and seek to enhance their power and control regardless of the cost to others. Given this intent, it is more difficult to motivate followers to perform unless they use deceit and manipulation. Therefore, it is not surprising that personalized leaders exhibited more extreme Machiavellian characteristics. It seems that the dark side of Machiavellianism could be closely aligned with the self-serving interests (Hogan, Raskin, \& Fazzini, 1990) of personalized leaders. In contrast, socialized leaders work toward the greater good of their followers, and to some extent have less need for deception or manipulation. In general, followers are more apt to do what needs to be done when it is in their best interest. Perhaps the brighter side of Machiavellianism is characterized by the Mach scores of socialized leaders.

Although we predicted that Machiavellianism would be positively related to performance, the results of the regression analyses indicate that Machiavellianism is negatively related to performance, albeit substantially less so when leader type and orientation are taken into account. These findings have two potential implications: 1) with regard to performance and 2) with regard to leader type and orientation. First of all, though we included numerous control variables and used multiple objective measures of performance, this finding is inconsistent with prior research regarding Machiavellianism and performance (Deluga, 2001; Simonton, 1986). One reason for this incongruence could be due to the present study's focus on long-term performance implications. Given that followers cannot be deceived or manipulated forever, it seems reasonable to hypothesize that Machiavellian behavior might be better suited for short-term performance. Perhaps future research should investigate the short-term and long-term performance implications of Machiavellianism. The findings may indicate that Machiavellian behaviors can win the battle but not the war. Along the same line, a much simpler explanation is available given that previous studies have used the same select sample of 39 American Presidents and have been unable to control for contextual factors such as level of industrialization or amount of political conflict in society (Deluga, 2001), both significant covariates in the present study. Separately, the second implication indicates that leader type and orientation are important for understanding Machiavellianism. More succinctly, to best understand Machiavellianism, researchers should account for leader type and orientation. In fact, future research should more carefully examine the overlapping behaviors exhibited by charismatic, ideological, and pragmatic leaders with socialized and personalized orientations and Machiavellian characteristics.

In summary, this study targeted an empirically unexplored and important domain of research (namely, the differential relationship between leader type, leader orientation, Machiavellianism, and performance). As such, the investigation contributes to and somewhat extends prior research (e.g., Deluga, 2001; Simonton, 1986). First, the data clarifies the 
relationship between Machiavellianism and charismatic leadership, especially with respect to ideological and pragmatic leadership. Second, the findings clearly outline the relationship between Machiavellianism and personalized and socialized leader orientations. Third, the results indicate that leader type and orientation aid substantially in the understanding of Machiavellianism. Fourth, the results extend prior research by Deluga (2001) in a number of ways. Although Deluga's (2001) study contributed to the field of leadership, it was limited to charismatic American presidents. This noteworthy limitation was improved upon in four ways: 1) the sample includes outstanding leaders across the domains of military, business, religion, and social reform, 2) the sample is made up of international male and female leaders, 3) the sample was extended to include non-charismatic leaders, specifically, pragmatic and ideological leaders, and 4) in addition to improving the generalizability of the sample, the present study controls for a number of significant contextual factors that were not taken in account in prior studies.

Although these findings evidence progress, more work needs to be done. Future research should capitalize on the current findings and further examine the relationship between Machiavellianism and performance in outstanding leaders, especially with respect to short-term and long-term implications. More importantly, given the variance leader type and leader orientation account for in addition to Machiavellianism, further research should be devoted to examining the potential overlapping behaviors exhibited by charismatic, ideological, and pragmatic leaders with socialized or personalized orientations and Machiavellian characteristics.

\section{References}

Bass, B. M. (1985). Leadership and performance beyond expectations. New York: Free Press.

Bass, B. M. (1990). ( $3^{\text {rd }}$ ed.). Bass and Stogdill's handbook of leadership: Theory, research, and managerial applications. New York: Free Press.
Bass, B. M., \& Avolio, B. J. (1994). Improving organizational effectiveness through transformational leadership. Thousand Oaks, CA: Sage.

Beyer, J. M. (1999). Taming and promoting charisma to change organizations. The Leadership Quarterly, 10, 307-330.

Christie, R. (1970). Scale construction. In R. Christie \& F.L. Geis (Eds.), Studies in Machiavellianism (pp. 10-34). New York: Academic Press.

Christie, R., \& Geis, F. (1970a). Studies in machiavellianism. New York: Academic Press.

Conger, J. A., \& Kanungo, R. N. (1988). Behavioral dimensions of charismatic leadership. In J. A. Conger \& R. N. Kanungo (Eds.), Charismatic leadership: The elusive factor in organizational effectiveness (pp. 78-97). San Francisco: Jossey-Bass.

Conger, J. A., \& Kanungo, R. N. (1998). Charismatic leadership in organizations. Thou and Oaks, CA: Sage Publications.

Deluga, R. J. (2001). American presidential Machiavellianism: Implications for charismatic leadership and rated performance. The Leadership Quarterly, 12, 334-363.

DePaulo, B. M., \& Rosenthal, R. (1979). Telling lies. Journal of Personality and Social Psychology, 37, 1713-1722.

Drazin, R., Glynn, M. A., \& Kazanjain, R. K. (1999). Multi-level theorizing about creativity in organizations: A sensemaking perspective. Academy of Management Review, 24, 286-329.

Drory, A., \& Gluskinos, U.M. (1980). Machiavellianism and leadership. Journal of Applied Psychology, 65(1), 81-86.

Evered, R. (1983). Who's talking about the future? An analysis of the U.S. presidents. Technological Forecasting and Social Change, 24, 61-77.

Fehr, B., Samsom, D., \& Paulhus, D. L. (1992). The construct of Machiavellianism: Twenty years later. In C. D. Spielberger \& J. N. Butcher (Eds.), Advances in personality assessment (vol. 9, pp. 77-116). Hillsdale, NJ: Erlbaum. 
Fiol, C. M., Harris, D., \& House, R. J. (1999). Charismatic leadership: Strategies for effecting social change. The Leadership Quarterly, 10, 449-482.

Fleisher, M. (1972). Machiavelli and the nature of political thought. New York: Atheneum.

Gardner, H. (1993). Creative Minds: An anatomy of creativity as seen through the eyes of Freud, Einstein, Picasso, Stravinsky, Eliot, Graham, and Gandhi. New York: Basic Books.

Gardner, W. L., \& Avolio, B. J. (1995). Charismatic leadership: The role of impression management. Paper presented at the meeting of the Academy of Management, Vancouver, B.C.

Gardner, W. L., \& Avolio, B. J. (1998). The charismatic relationship: A dramaturgical perspective. Academy of Management Review, 23, 32-58.

Geis, F. L. (1978). Machiavellianism. In H. London \& J. Exner (Eds.), Dimensions of personality (pp. 305-363). New York: Wiley.

Geis, L., \& Levy, M. (1970). The eye of the beholder. In search of the Machiavelli. In R. Christie \& F.L. Geis (Eds.), Studies of Machiavellianism (pp. 210-235). New York: Academic Press.

Geis, F., Christie, R., \& Nelson, C. (1970). In search of the Machiavel. In R. Christie \& F.L. Geis (Eds.), Studies in Machiavellianism (pp. 76-95). New York: Academic Press.

Gerring, J. (1997). Ideology: A definitional analysis. Political Research Quarterly, 50, 957-994.

Hantz, C.A. (1996). Ideology, pragmatism, and Ronald Reagan's world view: Full of sound and fury, signifying...? Presidential Studies Quarterly, 26, 942-949.

Hogan, R., Raskin, R., \& Fazzini, D. (1990). The dark side of charisma. In K. E. Clark \& M. B. Clark (Eds.), Measures of leadership (pp. 343-354). West Orange, NJ: Leadership Library of America, Inc.

House, R. J. (1995). Leadership in the $21^{\text {st }}$ century: A speculative inquiry. In A. Howard (Ed.), The changing nature of work (pp. 411-450). San Francisco, CA: JosseyBass.
House, R. J., \& Howell, J. M. (1992). Personality and charismatic leadership. The Leadership Quarterly, 3, 81-108.

Howell, J. M., \& Avolio, B. J. (1992). The ethics of charismatic leadership: Submission or liberation? Academy of Management Executive, 6(2), 43-54.

Hunt, J. G., Boal, K. B., \& Dodge, G. E. (1999). The effects of visionary and crisis responsive charisma on followers: An experimental examination of two kinds of charismatic leadership. The Leadership Quarterly, 10, 423-448.

Jacobsen, C., \& House, R. J. (2001). Dynamics of charismatic leadership: A process theory, simulation model, and tests. The Leadership Quarterly, 12, 75-112.

Klein, K. J., \& House, R. J. (1998). On fire: Charismatic leadership and levels of analysis. In F. Dansereau \& F. J. Yammarino (Eds.), Leadership: The multiple level approaches (pp. 3-22). Stanford, Connecticut: JAI Press.

Lewicki, R. J. (1983). Lying and deception: A behavioral model. In M. Bazerman \& R. J. Lewicki (Eds.), Negotiating in organizations (pp. 68-90). Beverly Hills, CA: Sage.

Lowe, K. B., Kroeck, K. G., \& Sivasubramaniam, N. (1996). Effectiveness correlates of transformational and transactional leadership: A meta-analytic review of the MLQ literature. The Leadership Quarterly, 7, 385-425.

Machiavelli, N. (1513/1966). The prince and The discourses. New York: Bantam Books.

Mansfield, H. C. (1996). Machiavelli's virtue. Chicago: The University of Chicago Press.

Martin, N. H., \& Sims, J. H. (1956). Thinking ahead: Power tactics. Harvard Business Review, 34 (6), 25-36, 140.

McHoskey, J. (1995). Narcissism and machiavellianism. Psychological Reports, 77, 755-759.

McHoskey, J.W., Worzel, W., \& Szyarto, C. (1998). Machiavellianism and psychopathy. Journal of Personality and Social Psychology, 74, 192-210. 
Meindl, J. R. (1990). On leadership: An alternative to the conventional wisdom. Research in Organizational Behavior, 12, 159-203.

Mills, C. W. (1967). The marxists. New York: Dell.

Mumford, M.D. (Ed.). (in press). Pathways to outstanding leadership: A comparative analysis of charismatic, ideological, and pragmatic leadership. Mahwah, NJ: Erlbaum Press.

Mumford, M.D., Gaddis, B., Strange, J.M., \& Scott, G. (in press). General Method. In M.D. Mumford (Ed.), Pathways to outstanding leadership: A comparative analysis of charismatic, ideological, and pragmatic leadership. Mahwah, NJ: Erlbaum Press.

Mumford, M.D., \& Van Doorn, J.R. (2001). The leadership of pragmatism: Reconsidering Franklin in the age of charisma. The Leadership Quarterly, 12, 279-309.

Mumford, M.D., Strange, J.M., \& Bedell, K.E. (in press). Introduction. In M.D. Mumford (Ed.), Pathways to outstanding leadership: A comparative analysis of charismatic, ideological, and pragmatic leadership. Mahwah, NJ: Erlbaum Press.

Mumford, M.D., Strange, J.M., Gaddis, B., Licuanan, B., \& Scott, G. (in press). Performance. In M.D. Mumford (Ed.), Pathways to outstanding leadership: A comparative analysis of charismatic, ideological, and pragmatic leadership. Mahwah, NJ: Erlbaum Press.

Mumford, M.D., Strange, J.M., \& Hunter, S.T. (in press). Conclusions. In M.D. Mumford (Ed.), Pathways to outstanding leadership: A comparative analysis of charismatic, ideological, and pragmatic leadership. Mahwah, NJ: Erlbaum Press.

O'Connor, J., Mumford, M. D., Clifton, T. C., Gessner, T. L., \& Connelly, M. S. (1995). Charismatic leaders and destructiveness: An historiometric study. The Leadership Quarterly, 6, 529-555.

Pfiffner, J. M. (1951). The supervision of personnel: Human relations in the management of men. Englewood Cliffs, $\mathrm{NJ}$ : Prentice-Hall.
Rejai, M. (1991). Political ideologies: A comparative approach. Armonk, New York: M.G. Sharpe.

Renshon, S. A. (1998). Analyzing the psychology and performance of presidential candidates at a distance: Bob Dole and the 1996 presidential campaign. The Leadership Quarterly, 9, 377-395.

Shamir, B., House, R. J., \& Arthur, M. B. (1993). The motivational effects of charismatic leadership: A self-concept based theory. Organizational Science, 4, 577-594.

Shamir, B., Zakay, E., Breinin, E., \& Popper, M. (1998). Correlates of charismatic leader behavior in military units: Subordinates attitudes, unit characteristics, and superiors' appraisals of leader performance. Academy of Management Journal, 41, 387-409.

Shapiro, D. L., Lewicki, R. J., \& Devine, P. (1995). When do employees choose deceptive tactics to stop unwanted change? A relational perspective. In R. Lewicki, B. Sheppard, \& R. Bies (Eds.), Research on negotiation in organizations (vol. 5, pp. 155-184). Greenwich, CT: JAI Press.

Shepperd, J. A., \& Socherman, R. E. (1997). On the manipulative behavior of low Machiavellians: Feigning incompetence to "sandbag" an opponent. Journal of Personality and Social Psychology, 72, 1448-1459.

Shrout, P. E., \& Fleiss, J. L. (1979). Interclass correlations: Uses in assessing rater reliability. Psychological Bulletin, 86, 420428.

Sigelman, L. (2002). Two Reagans? Genre imperatives, ghostwriters, and presidential personality profiling. Political Psychology, 23(4), 839-851.

Simonton, D. K. (1984). Genius, creativity, and leadership. Cambridge, MA: Harvard Univ. Press.

Simonton, D. K. (1986). Presidential personality: Biographical use of the Gough Adjective Check List. Journal of Personality and Social Psychology, 51, 149-160. 
Simonton, D. K. (1999). Significant samples: The psychological study of eminent individuals. Psychological Methods, 4, 425451.

Strange, J. M., \& Mumford, M. D. (2002). The origins of vision: Charismatic versus ideological leadership. The Leadership Quarterly, 13, 343-377.

Suedfeld, P., \& Wallace, M.D. (1995). President Clinton as a cognitive manager. In S.A. Renshon (Ed.), The Clinton presidency: Campaigning, governing, \& the psychology of leadership (pp. 215-233). Boulder, CO: Westview.

Weber, M. (1924). The theory of social and economic organizations. New York: Free Press.

Weber, M. (1947). The theory of social and economic organization (T. Parsons, translated). New York: Free Press.

Weick, K.E. (1995). Sensemaking in Organizations. Thousand Oaks, CA: Sage.

Wilson, D. S., Near, D., \& Miller, R. R. (1996). Machiavellianism: A synthesis of the evolutionary and psychological literatures. Psychological Bulletin, 119, 285-299.

Winter, D. G. (1987). Leader appeal, leader performance, and the motives profile of leaders and followers: A study of American presidents and elections. Journal of Personality and Social Psychology, 52, 196-202.

Wrightsman, L. S. (1991). Interpersonal trust and attitudes toward human nature. In J. P. Robinson, P. R. Shaver, \& L. S. Wrightsman (Eds.), Measures of personality and social psychological attitudes (vol. 1, pp. 373-412). New York: Academic Press.

Yorges, S. L., Weiss, H. M., \& Strickland, O. J. (1999). The effects of leader outcomes on influence, attributions, and perceptions of charisma. Journal of Applied Psychology, $84,428-436$.

Yukl, G. (1999). An evaluation of conceptual weaknesses in transformational and charismatic leadership theories. The Leadership Quarterly, 10, 285-305.

Yukl, G. (2001). Leadership in organizations $\left(5^{\text {th }}\right.$ ed.). Englewood Cliffs, NJ: PrenticeHall.
Zullow, H.M., Oettingen, G., Peterson, C., \& Seligman, M.E.P. (1988). Pessimistic explanatory style in the historical record: CAVing LBJ, presidential candidates, and East versus West Berlin. American Psychologist, 43, 673-682.

\section{Appendix}

Citation List for Biographies Used for Content Analysis

1. Chadha, Y. (1997). Gandhi: A life. New York: John Wiley \& Sons, Inc.

2. Ferrell, R.H. (1994). Harry S. Truman: A life. Columbia: University of Missouri Press.

3. Lyons, E. (1966). David Sarnoff. New York: Harper and Row.

4. Williams, T.H. (1969). Huey Long. New York: Vintage Books.

5. Franz, U. (1988). Deng Xiaoping. Boston: Harcourt Brace Janovich, Publishers. TRANSLATED.

6. Pruessen, R.W. (1982). John Foster Dulles: The road to power. New York: Free Press.

7. Clark, C.M. (2000). Kaiser Wilhelm II. London: Longman.

8. Crassweller, R.D. (1966). Trujillo: The life and times of a Caribbean dictator. New York: The MacMillan Company.

9. McDougal, D. (2001). Privileged son: Otis Chandler and the rise and fall of the L.A. Times dynasty. New York: Perseus Publishing. 10. Broderick, F.L. (1959). W.E.B. DuBois: Negro leader in a time of crisis. Stanford: Stanford University Press.

11. Watson, D.R. (1974). Georges Clemenceau: A political biography. New York: David McKay Company, Inc.

12. Seale. P. (1988). Asad of Syria: The struggle for the Middle East. Berkley: University of California Press.

13. Powers, R.G. (1987). Secrecy and power: The life of J. Edgar Hoover. New York: Free Press.

14. Dykhuizen, G. (1973). The life and mind of John Dewey. Carbondale: Southern Illinois University Press.

15. Lyons, E. (1964). Herbert Hoover: A biography. Garden City: Doubleday and Company, Inc. 
16. Lowenstein, R. (1995). Buffett: The making of an American capitalist. New York: Random House.

17. Mosely, L. (1985). Disney's World. New York: Stein and Day.

18. Wall, J.F. (1990). Alfred I. du Pont: The man and his family. New York: Oxford University Press.

19. Duiker, W.J. (2000). Ho Chi Minh. New York: Hyperion..

20. Lasky, V. (1981). Never complain, never explain: The story of Henry Ford II. New York: Richard Marek Publishers.

21. Diederich, B., \& Burt, A. (1991). Papa Doc: Haiti and its dictator. Maplewood: Waterfront Press.

22. Alaexander, R.J. (1979). Juan Domingo Peron: A history. Boulder: Westview Press.

23. Chandler, D.P. (1999). Brother number one: A politial biography of Pol Pot. Boulder: Westview Press.

24. Schwarzwaller, W. (1988). Rudolf Hess: the last Nazi. Bethesda: National Press, Inc.

25. Spence, H. (1969). Marcos of the Philippines. New York: The World Publishing Company.

26. Cohen, A., \& Taylor, E. (2000). American pharaoh: Mayor Richard J. Daley: His battle for Chicago and the nation. Boston: Little, Brown, and Company.

27. Warner, P. (1986). Kitchener: The man behind the legend. New York: Atheneum.

28. Bennett, L. (1976). A biography of Martin Luther King, Jr. Chicago: Johnson Publishing Company, Inc.

29. Bosworth, R.J.B. (2002). Mussolini. London: Arnold.

30. Young, H. (1989). One of us: A biography of Margaret Thatcher. London: Macmillan.

31. Preston, P. (1994). Franco: A biography. London: BasicBooks.

32. Garner, P. (2001). Profirio Diaz. London: Longman.

33. Rooney, D. (1988). Kwame Nkrumah: The political kingdom in the third world. New York: St. Martin's Press.

34. Lenin, H. (1983). Grand delusions: The cosmic career of John De Lorean. New York: The Viking Press.
35. Two biographies used:

a. Hyde, H. M. (1971). Stalin: The history of a dictator. New York: Farrar, Straus and Giroux.

b. Ulam, A.B. (1989). Stalin: The man and his era. New York: The Viking Press.

36. Knight, A. (1993). Beria: Stalin's first lieutenant. Princeton: Princeton University Press.

37. Hennessee, J. (1999). Betty Friedan: Her life. New York:Random House.

38. Gilbert, M. (1991). Churchill: A life. New York: Henry Holt and Company.

39. Bosanquet, M. (1968). The life and death of Dietrich Bonhoeffer. New York:Harper and Row, Publishers.

40. Zaffiri, S. (1994). Westmoreland: A biography of General William C. Westmoreland. New York:William Morrow and Company, Inc.

41. Brunk, S. (1995). Emiliano Zapata: Revolution and Betrayal in Mexico. Albuquerque: University of New Mexico Press.

42. Fraser, N., \& Navarro, M. (1980). Eva Peron. New York: W.W. Norton \& Company. 43. Stein, J. (1986). The world of Marcus Garvey: Race and class in modern society. Baton Rouge: Louisiana State University Press.

44. Segal, R. (1979). Leon Trotsky: A biography. New York: Pantheon Books.

45. Baker, L. (1969). Felix Frankfurter. New York: Coward-McCann, Inc.

46. Perry, B. (1991). Malcolm: The life of a man who changed black America. Barrytown: Station Hill Press.

47. Irving, D. (1989). Goring: A biography. New York: William Morrow and Company, Inc. 48. Shawcross, W. (1992). Murdoch: The making of a media empire. New York: Touchstone Press.

49. Norris, R.S. (2002). Racing for the bomb: General Leslie R. Groves, the Manhattan Project's indispensable man. Vermont: Steerforth Press.

50. Perret, G. (2001). Jack: A life like no other. New York: Random House.

51. Kaufman, M.T. (2002). Soros: The life and times of a messianic billionaire. New York: Alfred A. Knopf.

52. Frank, K. (2002). Indira: The life of Indira Nehru Gandhi. Boston: Houghton Mifflin Company. 
53. Anderson, J., \& May, R.W. (1952). McCarthy: The man, the senator, and the "ism." Boston: The Beacon Press.

54. Payne, R. (1973). The life and death of Adolf Hitler. New York: Praeger Publishers.

55. Anthony, K. (1954). Susan B. Anthony: Her personal history and era. New York: Doubleday \& Company, Inc.

56. Calic, E. (1982). Reinhard Heydrich: The chilling story of the man who masterminded the Nazi death camps. New York: Military Heritage Press. TRANSLATED

57. Sloane, A.A. (1991). Hoffa. Cambridge: The MIT Press.

58. Tilton, E.M. (1947). Amiable autocrat: A biography of Dr. Oliver Wendell Holmes. New York: Henry Schuman.

59. Kessner, T. (1989). Fiorello H. La Guardia and the making of modern New York. New York: McGraw-Hill Publishing Company. 60. Sperber, A.M. (1986). Murrow: His life and times. New York: Freundlich Books.

61. Falk, C.S. (1984). Love, anarchy, and Emma Goldman. New Brunswick: Rutgers University Press.

62. Steinberg, A. (1975). Sam Rayburn: A biography. New York: Hawthorn Books, Inc.

63. Short, P. (1999). Mao: A life. New York: Henry Holt and Company.

64. Fosdick, R.B. (1956). John D. Rockefeller, Jr.: A portrait. New York: Harper and Brothers, Publishers.

65. Mandel, B. (1963). Samuel Gompers: A biography. Yellow Springs: The Antioch Press.

66. Linn, J.W. (1935). Jane Addams: A biography. New York: D. Appleton-Century Company, Inc.

67. Wyden, P. (1987). The unknown Iacocca. New York: William Morrow and Company, Inc.

68. Bar-Zohar, M. (1966). The armed prophet: A biography of Ben Gurion. London: Arthur Barker Limited. TRANSLATED

69. Mosely, L. (1982). Marshall: Hero for our times. New York: Hearst Books.

70. McDougal, D. (1988). The last mogul: Lew Wasserman, MCA, and the hidden history of Hollywood. New York: Crown Publishers, Inc.

71. Polmar, N., \& Allen, T.B. (1982). Rickover. New York: Simon and Schuster.
72. Neff, J. (1989). Mobbed Up: Jackie Presser's high-wire life in the Teamsters, the Mafia, and the F.B.I. New York: The Atlantic Monthly Press.

73. Bosch. A. (1988). Reagan: An American story. New York: TV Books.

74. Gelderman, C. (1981). Henry Ford: The wayward capitalist. New York: The Dial Press.

75. Salvatore, N. (1982). Eugene V. Debs: Citizen and Socialist. Urbana: University of Illinois Press.

76. Maclean, F. (1980). Josip Broz Tito: A pictorial biography. New York: McGraw-Hill Book Company.

77. Moss, M. (1988). Palace coup: The inside story of Harry and Leona Helmsley. New York: Doubleday.

78. Griswold del Castillo, R., \& Garcia, R.A. (1995). Cesar Chavez: A triumph of spirit. Norman: University of Oklahoma Press.

79. Urquhart, B. (1971). Hammarskjold. New York: Alfred A. Knopf.

80. Hart, B.H.L. (1932). Foch: The man of Orleans. Boston: Little, Brown, and Company.

81. Maney, K. (2003). The maverick and his machine: Thomas Watson, Sr. and the making of IBM. Hoboken: John Wiley and Sons, Inc.

82. Kobler, J. (1992). Capone: The life and world of Al Capone. Greenwich: Fawcett Publications, Inc.

83. Byrne, J.A. (1999). Chainsaw: The notorious career of Al Dunlap in the era of profit-at-any-price. New York: HarperBusiness. 84. Smith, G. I. (1980). Ghosts of Kampala. New York: St. Martin's Press. (Idi Amin)

85. Lyon, P. (1974). Eisenhower: Portrait of the hero. Boston: Little, Brown, and Company.

86. Dubofsky, M., \& Van Tine, W. (1986). John L. Lewis: A biography. Urbana: University of Illinois Press.

87. Feiling, K. (1946). The life of Neville Chamberlain. London: Macmillan \& Co. Ltd.

88. Felsenthal, C. (1993). Power, privilege and the Post: The Katherine Graham story. New York: G.P Putnam's Sons.

89. James, D.C. (1970). The years of MacArthur. Boston: Houghton Mifflin Company. 
90. Fraser, D. (1993). Knight's cross: A life of Field Marshall Erwin Rommel. New York: Harper Collins Publishers.

91. Hirshson, S.P. (2002). General Patton: A soldier's life. New York: Harper Collins Publisher.

92. Posner, G. (2002). Motown: Music, money, sex and power. New York: Random House.

93. McCauley, M. (1998). Gorbachev. London: Longman.

94. Kaye, T. (1989). Lech Walesa. New York: Chelsea House Publishers.

95. Summers, A., \& Swan, R. (2000). The arrogance of power: The secret world of Richard Nixon. New York: Viking.

96. Crozier, B. (1973). De Gaulle. New York: Charles Scribner's Sons.

97. Morgan, T. (1985). FDR: A biography. New York: Simon and Schuster.

98. Byron, C. (2002). Martha Inc.: The incredible story of Martha Stewart Living Omnimedia. New York: John Wiley and Sons, Inc.

99. Dinges, J. (1990). Our man in Panama: How General Noriega used the United States and made millions in drugs and arms. New York: Random House.

100. Unger, I., \& Unger, D. (1999). LBJ: a life. New York: John Wiley \& Sons, Inc.

101. Mango, A. (2000). Attaturk. New York: The Overlook Press.

102. Padfield, P. (1990). Himmler: Reichsfuhrer-SS. London: MacMillan.

103. Strouse, J. (1999). Morgan: American financier. New York: Random House.

104. Davis, J.H. (1993). Mafia dynasty: The rise and fall of the Gambino crime family. New York: HarperPaperbacks.

105. Hirst, D., \& Beeson, I. (1981). Sadat. London: Faber and Faber Limited.

106. Brands, H.W. (1997). T.R.: The Last Romantic. New York: BasicBooks.

107. Murray, R.K. (1969). The Harding era: Warren G. Harding and his administration. Minneapolis: University of Minnesota Press.

108. Fischer, L. (1964). The life of Lenin. New York: Harper and Row.

109. Lacouture, J. (1973). Nasser. New York: Alfred A. Knopf. TRANSLATED.
110. Krass, P. (2002). Carnegie. New Jersey: John Wiley and Sons, Inc.

111. Manchester, W. (1968). The arms of Krupp: 1587-1968. Boston: Little, Brown and Company.

112. Caro, R.A. (1974). The power broker: Robert Moses and the fall of New York. New York: Alfred A. Knopf.

113. Murray-Brown, J. (1973). Kenyatta. New York: E.P. Dutton \& Co., Inc.

114. Two biographies used:

Cook, B.W. (1992). Eleanor Roosevelt: Volume a. One 1884-1933. New York: Viking.

b. Cook, B.W. (1999). Eleanor Roosevelt: Volume Two 1933-1938. New York: Viking.

115. Harlan, L.R. (1872). Booker T. Washington: The making of a black leader, 1856-1901. New York: Oxford University Press.

116. Higham, C. (1993). Merchant of dreams: Louis B. Mayer, M.G.M., and the secret Hollywood. New York: Donald I. Fine, Inc.

117. Szulc, T. (1986). Fidel: A critical portrait. New York: William Morrow and Company, Inc.

118. Coogan, T.P. (1990). Michael Collins: A biography. London: Hutchinson.

119. Trimble, V.H. (1990). Walton: The inside story of America's richest man. New York: Dutton.

120. Heckscher, A. (1991). Woodrow Wilson. New York: Charles Scribner's Sons. 